\title{
Three Cases of Adenomyoepithelioma: An Unusual Breast Neoplasm
}

\author{
Murat Özgür Kıllı̧̧ ${ }^{1}$, Meral Sen $^{2}$, Cenap Dener ${ }^{2}$, Dilek Kösehan ${ }^{3}$, Sibel Yenidünya ${ }^{4}$
}

\begin{abstract}
Adenomyoepithelioma of the breast is an unusual tumor characterized by biphasic proliferation of both epithelial and myoepithelial cells. Although most of these tumors have a benign course, a small number of malignant lesions have been reported in the literature. Adenomyoepithelioma is also characterized by propensity for local recurrence. Therefore, the sufficiency of initial surgery plays very important role in the management of these tumors. Due to the potential to malignant transformation and high risk of local recurrence, totally excision with wide margins should be performed in surgical treatment of these tumors. In this paper, three cases of adenomyoepithelioma of the breast with different clinical presentations and radiological findings were reported. J Clin Exp Invest 2016; 7 (1): 91-93
\end{abstract}

Key words: Adenomyoepithelioma, breast, diagnosis, treatment

\section{$\ddot{U} c ̧$ Adenomiyoepitelyoma Olgusu: Nadir Bir Meme Tümörü}

\section{ÖZET}

Memenin adenomiyoepitelyoması hem epitelyal hem de miyoepitelyal hücrelerin bifazik proliferasyonu ile karakterize nadir bir tümördür. Bu tümörlerin çoğu benign seyirli olmasına karşın, az sayıda malign lezyonlar da literatürde bildirilmiştir. Adenomiyoepitelyoma aynı zamanda lokal nükse eğilim ile de karakterizedir. Bu nedenle, bu tümörlerin tedavisinde ilk uygulanan cerrahinin yeterliliği çok önemli bir rol oynar. Malign transformasyon potansiyeli ve yüksek lokal nüks riski nedeniyle, bu tümörlerin cerrahi tedavisinde geniş sınırlarla total eksizyon uygulanmalıdır. Bu yazıda, farklı klinik prezentasyonları ve radyolojik bulguları olan üç meme adenomiyoepitelyoması olgusu bildirilmiştir.

Anahtar kelimeler: Adenomiyoepitelyoma, meme, tanı, tedavi.

\section{INTRODUCTION}

Tumors with simultaneously proliferation of both epithelial and myoepithelial cells are called adenomyoepitheliomas (AMEs). These lesions were first described in salivary gland by Hamperl in 1970 [1]. AME is a rare neoplasm of the breast and usually occurs in women [2]. In the literature, it has been reported as single case reports or small case series. Centrally located nontender palpable breast mass is the most frequent clinical finding; however, it may be detected as an incidental finding at routine screening mammography [3]. Although these tumors are generally considered to be benign, malignant transformations and distant metastases have been also reported [4]. AME is also characterized by propensity for local recurrence mainly due to incomplete surgical excision. Therefore, totally excision with wide margins is generally recommended as main surgical approach. The prognosis of AME is usually good when the initial treatment is sufficient. Herein, three cases of AME with different clinical presentations and various radiological findings were reported and discussed with the relevant literature.

\section{Case 1}

A 48-year-old woman presented with a mass in her right breast. On examination, a hard nodularity about $1 \mathrm{~cm}$ in size was found. Mammography showed a focal asymmetric density. In addition, a hypoechoic solid lesion, $7 \mathrm{~mm}$ in diameter, was detected on ultrasonography (US). This lesion was evaluated as an adenosis in fine-needle aspiration biopsy, and then was completely removed with wide margins. Pathological

${ }^{1}$ Clinic of General Surgery, Numune Training and Research Hospital, Ankara, Turkey

2 Department of General Surgery, Turgut Ozal University, Ankara, Turkey

${ }^{3}$ Department of Radiology, Turgut Ozal University, Ankara, Turkey

${ }^{4}$ Department of Pathology, Turgut Ozal University, Ankara, Turkey

Correspondence: Murat Özgür Kılıç,

Clinic of General Surgery, Numune Training and Research Hospital, Ankara, Turkey Email: murat05ozgur@hotmail.com

Received: 28.10.2015, Accepted: 19.12.2015

Copyright (C) JCEI / Journal of Clinical and Experimental Investigations 2016, All rights reserved 
examination revealed a benign AME. No recurrence was observed during the follow up period of 3 years.

\section{Case 2}

A 39-year-old female patient presented with a firm mass in the left breast. She underwent an excisional biopsy for an adenosis in another hospital one year ago. On physical examination, a palpable $4 \mathrm{~cm}$ mass with smooth surface was found in the same localization of the previous surgery. US confirmed a hypoechoic, multi-lobulated solid lesion with several micro-calcifications near the areola. On Doppler US, the mass showed increased vascular flow. A lumpectomy was performed, and the excised lesion was diagnosed as AME in pathological evaluation. This patient is still healthy and shows no signs of recurrence for 30 months.

\section{Case 3}

A 47-year-old female was admitted to our unit with a peri-areolar lump in her right breast. She had a family history of breast cancer. On physical examination, a palpable peri-areolar irregularity with a suspicion of malignancy was found at the 9 o'clock position. Mammography showed a $2 \times 1 \mathrm{~cm}$ nodular opacity with irregular borders. In addition, a hypoechoic, macrolobulated, vertically oriented solid lesion (BI-RADS 4B) measuring about $1 \mathrm{~cm}$ was detected on US. Doppler US showed no detectable vascularity within the lesion. Additionally, qualitative elastography revealed that the lesion had an ES score of 4, stiff at most parts with minimal deformation (Figure 1A, B). Tru-cut biopsy findings were consistent with AME. Lumpectomy was performed for the breast lump. On histopathology, the lesion was composed of round glands and solid clusters consisting both epithelial and myoepithelial cells. Immunohistochemically, myoepithelial cells expressed CD10, calponin, P63, cytokeratin 5 and S-100; however, epithelial cells showed positive staining with cytokeratin 7 . Finally, the lesion was diagnosed as AME according to all these pathological findings (Figure 2). At present, the patient shows no sign of tumor recurrence within the follow-up period of 2 years.

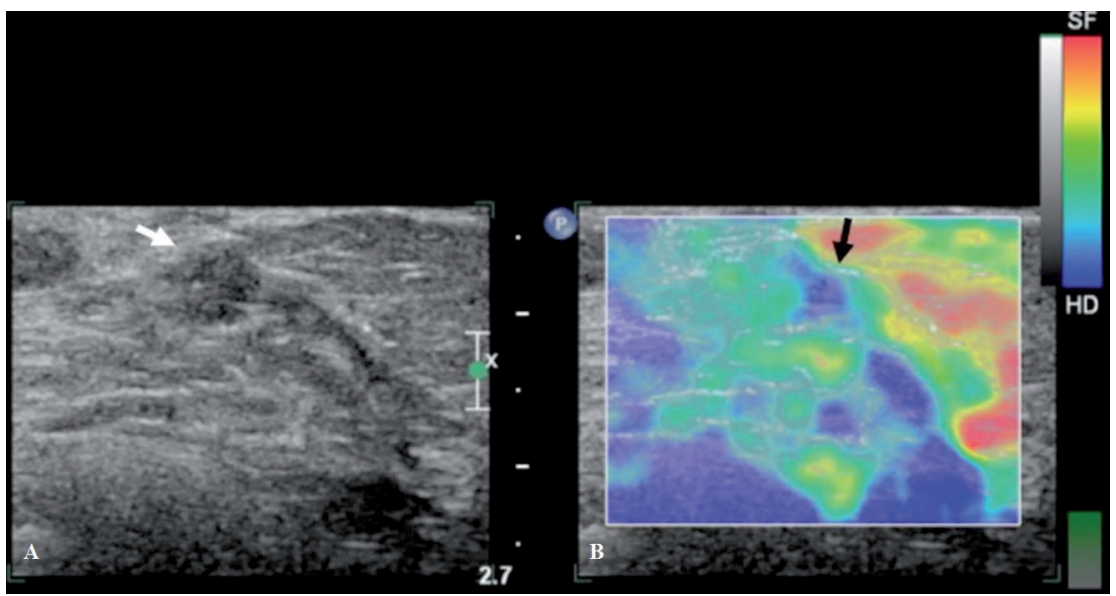

\section{DISCUSSION}

Adenomyoepithelioma is an unusual breast tumor that is generally considered to be benign or to have a low malignant potential. This tumor is generally less than $5 \mathrm{~cm}$ in size as in our cases [5]. On physical examination, AME of the breast is usually found as a solid mass with smooth surface, similar to a fibroadenoma. Macroscopically, the gross appearance is that of a solid tumor which is well circumscribed by a fibrous pseudocapsule of condensed breast tissue. On the other hand, as in our case 3, these tumors may be presented with various morphological features mim-
Figure 2. Well circumscribed nodular lesion with inner layer of epithelial cells (black arrow) and outer layer of myoepithelial cells (white arrow) (H\&E×100).
Figure 1. (A) Hypoechoic, macrolobulated, vertically oriented solid lesion measuring about $1 \mathrm{~cm}$ detected on ultrasonography. Doppler ultrasonography showed no detectable vascularity in the lesion. lesion (white arrow) revealed that the lesion was ES score 4, stiff at most parts (blue component-black arrow) with minimal deformation (green component - red arrow). (BI-RADS 4B) (white arrow) was 
icking a malignant lesion. The margins of the tumor in case 3 was irregular and indistinct, due to the lack of an apparent fibrous capsule and multinodular growth pattern. Therefore, correct preoperative diagnosis of AME is very important for surgical planning.

Benign AME has nonspecific radiological findings in addition to various clinical features. The most frequent sonographic findings are irregular borders, hypo-echogenicity, and increased peripheral vascularity [6]. The mammographic findings of AME are also nonspecific. Sonoelastography is a new diagnostic method in the evaluation of breast lesions, and enables an evaluation of tissue elasticity and hardness. It can provide additional information on breast lesions over conventional sonography and mammography. Malignant lesions have a harder structure than benign lesions, and therefore are less elastic due to increased fibrosis and desmoplastic reaction in their structure. When used in conjunction with B-mode US, the latter's sensitivity was increased [7].

AME often has a benign clinical course; however, malignant transformation can rarely develop from one or both cellular components [8]. Malignant lesions, especially larger than $2 \mathrm{~cm}$, have higher predilection for distant metastases [9]. Common sites of metastasis are lung, brain and thyroid. Due to difficulty in distinguishing benign and malignant lesions in fine needle aspiration biopsy [10], tru-cut biopsy is more valuable in diagnosis of AME. The surgical planning was based on the results of tru-cut biopsies in our cases.

These tumors are characterized by propensity for local recurrence. Incomplete surgical excision is mostly responsible for this condition. In patients with recurrent lesions, re-excision is the choice of the treatment. These tumors also have a little risk of malign transformation. Therefore, the sufficiency of initial surgical treatment has a critical role in the management of AME. Complete surgical excision with adequate margins is the recommended treatment modality for AME.

In conclusion, AME of breast is a rare and mostly benign tumor. Due to its rarity, diagnosis and optimal therapy are problematic issues for the clinicians. The main treatment of these tumors should be totally excision with wide margins because of potential for malignant transformation and high propensity of local recurrence. These patients should also be followed up regularly after surgery.

Declaration of Conflicting Interests: The authors declare that they have no conflict of interest.

Financial Disclosure: No financial support was received.

\section{REFERENCES}

1. Hamperl H. The myothelia (myoepithelial cells). Normal state; regressive changes; hyperplasia; tumors. Curr Topics Pathol 1970;53:161-220.

2. Ruiz-Delgado ML, López-Ruiz JA, Eizaguirre B, et al. Benign adenomyoepithelioma of the breast: imaging findings mimicking malignancy and histopathological features. Acta Radiol 2007;48:27-29.

3. Howlett DC, Mason CH, Biswas S, et al. Adenomyoepithelioma of the breast: spectrum of disease with associated imaging and pathology. AJR 2003;180:799-803.

4. Firat U, Keleş A, Mızrak B. Yüksek Ki-67 indeksi ile birlikte memenin malign adenomiyoepitelyoması: Literatür eşliğinde olgu sunumu. J Clin Exp Invest 2011;2:425-429.

5. Harigopal M, Park H, Chen X, Rosen PP. Pathologic quiz case: a rapidly increasing breast mass in a postmenopausal woman. Malignant adenomyoepithelioma. Arch Pathol Lab Med 2004;128:235-236.

6. Park YM, Park JS, Jung HS, et al. Imaging features of benign adenomyoepithelioma of the breast. J Clin Ultrasound 2013;41:218-223.

7. Hatzung G, Grunwald S, Zygmunt M, et al. Sonoelastography in the diagnosis of malignant and benign breast lesions: initial clinical experiences. Ultraschall Med 2010;31:596603.

8. Petrozza V, Pasciuti G, Pacchiarotti A, et al. Breast adenomyoepithelioma: a case report with malignant proliferation of epithelial and myoepithelial elements. World J Surg Oncol 2013;11:285.

9. Behranwala KA, Nasiri N, A'Hern R, Gui GP. Clinical presentation and long-term outcome of pure myoepithelial carcinoma of the breast. Eur J Surg Oncol 2004;30:357-361.

10. Iyengar P, Ali SZ, Brogi E. Fine-needle aspiration cytology of mammary adenomyoepithelioma: a study of 12 patients. Cancer 2006; 108:250-256 